\title{
University of Ilorin Academic Staffs' Perception of the Harmonisation of Academic Programmes and Qualifications
}

\author{
Foluke N. Bolu-Steve ${ }^{1, *}$, Bola O. Makinde ${ }^{2}$, Joshua A. Omotosho ${ }^{3}$ \\ ${ }^{1}$ University of Ilorin [* Corresponding author: bolusteve2002@yahoo.com], ${ }^{2}$ University of \\ Lagos, ${ }^{3}$ University of Cape Coast
}

\begin{abstract}
This study examined University of Ilorin academic staffs' perception of harmonization of academic programmes and qualifications in West Africa. The findings were that there is a significant difference in the academic staffs' perceptions by gender and duration of university teaching experience. However, no significant difference in perception of harmonisation was found on the basis of the respondents' departments and academic ranks. On the basis of these findings, the researchers recommended that ECOWAS provides funds to encourage academic activities that foster harmonization among cooperating member states. It is argued that the organisation can also organize trainings and workshops for stakeholders on harmonization of academic programmes and qualifications. This will help to update the academic staffs' knowledge of harmonisation of programmes and qualifications.
\end{abstract}

Keywords: Harmonisation; Mobility; Internationalisation.

\section{$1 \quad$ Introduction}

Education is seen as bedrock of development in any nation. The term "education" can be defined as a process of transmitting the cultural heritage, stabilizing the present thereby positively shaping the future. This process involves the development of the cognitive, affective and psychomotor aspects of the learners (Ibrahim, 2006). Education is the act of acquiring general knowledge, developing power of reasoning and judgment which prepares one intellectually for a mature life. Right education has a way of transmitting accumulated knowledge, skills, customs and values from one generation to another. An educated person is one that has access to optimal state of mind regardless of situation. Such a person is able to perceive accurately, think 
clearly and act effectively to achieve selected goals. Education also refers to the process of learning and acquiring information. The formal system of education is done through institutions such as the school. Basic and advanced skills are taught in school, which makes the students employable in the world of work (Alexis, 2011). In short, education is future- oriented and it is all about development and growth. The education system in Nigeria is guided by the broad National Policy on Education and it involves the development of individuals in order to equip them to make some contribution to human development according to the best of their capability (Wilson, 2003).

In Africa, there are different systems of education and they are normally based on the ideology of each country. The major goal of harmonization of academic programmes and qualifications includes fostering comparability among qualifications, enhancing the global competitiveness of African universities, promoting the mobility of students and academic staff across the continent, bridging the gap between disparate educational systems that exist as a result of colonial legacies, providing an integrating platform for dialogue, facilitating effective quality assurance mechanism, and ensuring that African higher education becomes a dynamic force (Hoosen, Butcher \& Khamati, 2009). The lack of recognition of different forms of certification has limited African integration and mobility of students across African countries. Africa Union (2008) stated that the Commission has therefore embarked on the process of developing a framework for the harmonization of higher education programmes on the continent. With the introduction of harmonization programmes, countries can share technologies and at the same time facilitate good educational policies (Associations of African Universities, 2004).

Harmonization of academic programmes refers to the recognition of certificates from any West African countries as valid by the competent authorities (International Conference on Accreditation, 2006). Sabaya (2004) revealed that African countries are moving towards regional integration through the efforts of Africa Union Commission. The major purpose of Africa Union is based on building a united and strong Africa that focuses on promoting peace, security and stability as prerequisites for implementing the development and integration agenda of the African Nations (African Union Commission, 2004). Therefore the mission policy of Africa Union involves the exchange of experience and harmonization of policies and programmes within Africa.

In 1998, the education ministers of France, Italy, Great Britain and Germany gathered in Paris to sign the Sorbonne Declaration which was aimed at harmonizing the architecture of the European Higher Education systems (Sorbonne Declaration, 1998). The Bologna Declaration which was signed by 29 European education ministers led to the Bologna Process. The major aim of the Bologna Process was the creation of harmonized programmes within the European Higher Education which will help academic staff and students to 
move with ease for employment (Bologna Declaration, 1999). The Arusha Convention (2008) is Africa's primary strategy and framework for the recognition of qualifications obtained from different African countries (African Union, 2008). According to Ogbe (2007), ECOWAS signed a protocol on education and training which resulted in the adoption of a general convention on the recognition and equivalence of degrees, diplomas, certificates and other qualifications in ECOWAS member states. The Arusha Regional Convention was based on the Recognition of Higher Education Studies and Degrees in Africa. This was adopted in the year 1981, with a view to promoting continental cooperation through the academic mobility of lecturers and students. Arusha convention was aimed at complementing United Nations Economic Commission for Africa's (UNECA's) efforts towards the promotion of international academic mobility. It is also aimed at facilitating training of human resources in order to promote the creation and application of knowledge, so as to improve the quality of higher education. UNECA will identify, support and create synergy between West African countries and relevant agencies at continental and regional levels (Shabani, 2004).

Sawyerr (2002) noted that harmonization of academic programmes promotes international and regional cooperation by creating awareness and encouraging African integration. This will equally facilitate the quality of education and comparability of qualifications awarded across African countries. Harmonization process can also help to develop good quality assurance mechanism and at the same time enhance the quality of academic programmes. Also, when African countries have the same benchmark for academic programmes, good networking among all stakeholders can be promoted. Naido (2004) affirmed that promoting human resource development, mismatch between skills and acquired academic qualification and brain drains are the major challenges among African countries.

\subsection{Statement of the Problem}

Harmonization of academic programmes and qualifications has become an issue of concern to different countries because there are different systems of education based on different national values and legacies across Africa. Despite the availability of the benchmark provided by the National University Commission (NUC) in Nigeria, there are still differences in the delivery of courses from one university to another. The task of harmonizing all these courses can be very challenging. The lack of recognition of different forms of certification has discouraged research and collaborative efforts within Africa (Magagula, 2005). Comparing higher educational programmes in a meaningful way is one of the biggest challenges in regional harmonization processes (Jokivirta, 2006). Such a task would be capital intensive and as such most 
countries have refused to be signatories to the harmonization process in West Africa (African Union Commission, 2004). The development of benchmark standards for related programmes within the West African region is a major challenge. Knight (2006) carried out a research on higher education across borders, Jokivirta (2006) looked at foreign higher education activity in Francophone Africa, while Magagula (2005) worked on the benefits and challenges of cross-border higher education in developing countries. None of these researchers has worked on the perception of stakeholders in Nigeria. Hence, taking the case of University of Ilorin, we investigated the way academic staffs in Nigeria perceive the harmonization of academic programmes and qualifications in West Africa.

\subsection{Purpose of the Study}

The purpose of this study is to look at the perception of university academic staff in Nigeria on harmonization academic programmes and qualification in West Africa. This study intends to find out the influence of variables such as the staff's gender, faculty, academic status and university teaching experience on harmonization of academic programmes and qualifications in West Africa. This study will be of benefit to tertiary institutions, especially those in West Africa. It will also be useful to the Africa initiatives on higher education, UNESCO and other education policy makers.

\subsection{Research Hypotheses}

1. There is no significant difference in the perception of university academic staff in Nigeria on harmonization of academic programmes and qualifications in West Africa on the basis of gender.

2. There is no significant difference in the perception of university academic staff in Nigeria on harmonization of academic programmes and qualifications in West Africa on the basis of faculty.

3. There is no significant difference in the perception of university academic staff in Nigeria on harmonization of academic programmes and qualifications in West Africa on the basis of academic rank.

4. There is no significant difference in the perception of university academic staff in Nigeria on harmonization of academic programmes and qualifications in West Africa on the basis of university teaching experience. 


\section{$2 \quad$ Methodology}

The study adopted the descriptive survey method because it allowed the researchers to collect data and describe it in a systematic manner (Adana, 1996). The target population consisted of all academic staff in the University of Ilorin. For the purpose of this study, University of Ilorin was purposively selected because the University is unique with uninterrupted academic calendar, it is located in the transition zone between the North and South, and it is in a confluence city of the country. This position allows for collaboration among various universities within the country. The researchers purposively selected 5 departments in the faculties of Science, Arts, Social Sciences and Education. Simple random sampling was used in selecting 10 participants from each of the departments. Thus, a total of 200 respondents participated in the study.

The questionnaire was given to four experts in the related field. These experts affirmed that the instrument covered the intended contents and was, therefore, valid. The reliability of the instrument used for the study was established using test-retest method within an interval of four weeks. The Pearson Product-Moment Correlation Coefficient was used to compute the correlation coefficient of the instrument. A reliability co-efficient of 0.74 was obtained. Hence the instrument was adjudged to be reliable.

The "Harmonization of Academic Programmes and Qualifications in West Africa Questionnaire (HAPQWAQ) was used. Items on the questionnaire were derived from information obtained from review of related literature. The instrument had two sections: A and B. Section A contained demographic data while section B consisted of items on perception of university academic staff on harmonization of programmes and qualifications in West Africa. A four-point Likert type rating scale response format was adopted for use in Section B thus: Strongly Agree - 4 points, Agree - 3 points, Disagree - 2 points, and Strongly Disagree -1point. The questionnaire contained 20 items. Frequency counts and simple percentages were used to analyse the descriptive data while mean scores and ranking were used to answer the research question. The hypotheses were tested using both the t-test and analysis of variance (ANOVA) statistical methods at the .05 level of significance.

\section{$3 \quad$ Findings}

Table 1 shows the distribution of respondents. 
Table 1: Distribution of Respondents

\begin{tabular}{llcc}
\hline Variable & Categories & Count & Percentage \\
\hline Gender & Male & 131 & 66 \\
& Female & 69 & 35 \\
Faculty & Total & 200 & 100 \\
& Science & 50 & 25 \\
& Arts & 50 & 25 \\
Academic status & Social Science & 50 & 25 \\
& Education & 50 & 25 \\
& Ass Lecturer -Lecturer 1 & 200 & 100 \\
Teaching Experience & Senior Lecturer to Professor & 120 & 60 \\
& Total & 80 & 40 \\
& Below 1-5 years & 86 & 43 \\
& 6-12 years & 50 & 25 \\
& 13 years and above & 64 & 32 \\
& Total & 200 & 100 \\
\hline
\end{tabular}

Table1 shows that $131(80.5 \%)$ were males, while $39(19.5 \%)$ of the respondents were females, $50(25 \%)$ respondents were selected from each of the faculties, i.e. Science, Arts, Social Science and Education respectively. The table also shows that $120(60 \%)$ of the respondents were between the statuses of Asst. Lecturer and Lecturer I, while $80(40 \%)$ of the respondents were between the statuses of Senior Lecturer and Professor. 86 (43\%) of the respondents have a university teaching experience of between 1 and 5 years, 50 $(25 \%)$ of the respondents have a university teaching experience of between 6 and 11years, while $64(32 \%)$ of the respondents have a university teaching experience of 12 years and above. Table 2 ranks the perceived contributions of harmonization of academic programmes and qualifications in West Africa. 
Table 2: Perceived Contributions of Harmonization of Academic Programmes and Qualifications in West Africa

\begin{tabular}{llc}
\hline Contribution & Mean & Rank \\
\hline Promotes collaborative research. & 3.66 & $1^{\text {st }}$ \\
Standardizes curriculum among African nations. & 3.43 & $2^{\text {nd }}$ \\
Fosters information exchange among students and staff of & 3.41 & $3^{\text {rd }}$ \\
African universities. & 3.39 & $4^{\text {th }}$ \\
Enhances the quality of education in Africa. & 3.34 & $5^{\text {th }}$ \\
Helps facilitate the comparability of qualifications awarded & & \\
across Africa. & 3.34 & $6^{\text {th }}$ \\
Helps foster academic integration. & 3.28 & $7^{\text {th }}$ \\
Fosters professional mobility for employment. & 3.26 & $8^{\text {th }}$ \\
Helps education system to inter-operate to benefit Africa. & 3.20 & $9^{\text {th }}$ \\
Improves the quality of African universities. & 3.18 & $10^{\text {th }}$ \\
Helps to develop good quality assurance mechanism. & 3.10 & $11^{\text {th }}$ \\
Enhances improved global rating of African universities. & 3.06 & $12^{\text {th }}$ \\
Helps in the acquisition and development of high technological & & \\
skills. & 3.03 & $13^{\text {th }}$ \\
Promotes unity among African nations. & 2.87 & $14^{\text {th }}$ \\
Helps to bridge digital divide. & 2.84 & $15^{\text {th }}$ \\
Helps in the management of academic resources. & 2.70 & $16^{\text {th }}$ \\
Leads to improved global rating of African universities. & 2.68 & $17^{\text {th }}$ \\
Encourages youth empowerment. & 2.54 & $18^{\text {th }}$ \\
Reduces corruption tendencies among African nations. & 2.46 & $19^{\text {th }}$ \\
Makes education available and affordable. & 2.32 & $20^{\text {th }}$ \\
Alleviates social and economic poverty. & & \\
\hline
\end{tabular}

Table 2 shows that perceived contribution of harmonization of academic programmes and Qualification promote collaborative research. This has the highest mean score of 3.66 and was therefore ranked $1^{\text {st }}$. The item that was ranked $2^{\text {nd }}$ shows that Harmonization of academic programmes and qualifications in West Africa has helped to standardize curriculum among Africa nations with a mean a score of 3.43 .

To test the hypothesis that there is no significant difference in the perception of academic staff on harmonization of academic programmes and qualifications in West Africa on the basis of gender, the findings were subjected to a t-test. The results are summarized in Table 3.

Table 3: Perception of harmonization of academic programmes and qualifications by gender

\begin{tabular}{lllllll}
\hline Gender & N & Mean & SD & Df & Cal. t-value & Crit. t-value \\
\hline Male & 161 & 61.81 & 8.17 & 198 & $2.44^{*}$ & 1.96 \\
Female & 39 & 58.30 & 7.50 & & & \\
\hline *Significant, $p<0.05$ & & & & &
\end{tabular}


Table 3 shows a calculated $t$-value of 2.44 and a critical $t$-value is 1.96 . The calculated $t$-value is greater than the critical $t$-value. The hypothesis is rejected; $t(\mathrm{df}=198)=2.44, \mathrm{p}=0.05$. Thus, there is a significant difference in the perception of academic staff on harmonization of academic programmes and qualifications in West Africa on the basis of gender.

To test the hypothesis that there is no significant difference in the perception of academic staff on harmonization of academic programmes and qualifications in West Africa on the basis of faculty, the findings were subjected to ANOVA. The results are shown in Table 4.

Table 4: Analysis of Variance in Perceptions on the Basis of Faculty

\begin{tabular}{llllll}
\hline Source & df & SS & Mean Square & Cal. F-value & Crit. F-value \\
\hline Between & 3 & 17.735 & 5.91 & 0.08 & 2.60 \\
Groups & & & & & \\
Within Groups & 196 & 13205.620 & 67.37 & & \\
Total & 199 & 13223.355 & & & \\
\hline
\end{tabular}

Table 4 shows the F-value calculated of 0.08 and a critical value of 2.60. The calculated F-value is less than the critical F-value. The hypothesis is accepted. Hence, there is no significant difference in the perception of academic staff on harmonization of academic programmes and qualifications in West Africa on the basis of faculty.

To test the hypothesis that there is no significant difference in the perception of academic staff on harmonization of academic programmes and qualifications in West Africa on the basis of academic rank, the findings were subjected to Ttest. The results are shown below in table 5 .

Table 5: Perceptions of harmonization by Academic Rank

\begin{tabular}{lllllll}
\hline Academic Status & N & Mean & SD & df & Cal. t-value & Crit. t-value \\
\hline AL - L1 & 120 & 61.02 & 8.05 & 198 & 0.23 & 1.96 \\
SL - Prof. & 80 & 61.30 & 8.33 & & & \\
\hline
\end{tabular}

Table 5 shows a calculated t-value of 0.23 and a critical t-value is 1.96 . The calculated t-value is less than the critical t-value. The hypothesis is accepted. Thus, there is a significant difference in the perception of academic staff on harmonization of academic programmes and qualifications in West Africa on the basis of academic status.

To test the hypothesis that there is no significant difference in the perception of academic staff on harmonization of academic programmes and qualifications in West Africa on the basis of teaching experience, the findings were subjected to ANOVA on Table 6. 
Table 6: Analysis of Variance in Perceptions by Teaching Experience

\begin{tabular}{lccllll}
\hline Source & df & SS & $\begin{array}{l}\text { Mean } \\
\text { Square }\end{array}$ & $\begin{array}{l}\text { Cal. } \\
\text { value }\end{array}$ & $\begin{array}{l}\text { F- } \\
\text { Crit. } \\
\text { value }\end{array}$ & F- \\
\hline $\begin{array}{l}\text { Between } \\
\text { Groups }\end{array}$ & 2 & 1173.897 & 586.94 & $9.59^{*}$ & 3.00 & \\
$\begin{array}{l}\text { Within Groups } \\
\text { Total }\end{array}$ & 197 & 12049.458 & 61.164 & & \\
\hline *Significant, $\mathrm{p}<0.05$. & 13223.355 & & & & \\
\hline
\end{tabular}

Table 6 shows the F-value calculated of 9.59 and a critical value of 3.00. The calculated F-value is greater than the critical F-value. Therefore, the hypothesis is rejected; $F(\mathrm{df}=2,197)=9.59, \mathrm{p}=0.05$. Hence, there is a significant difference in the perception of academic staff on harmonization of academic programmes and qualifications in West Africa on the basis of university teaching experience. The Duncan Multiple Range Test (DMRT) was used as a post-hoc test. The results of the DMRT procedure are displayed in Table 7.

Table 7: Duncan's Multiple Range Test on the Means of University Teaching Experience

\begin{tabular}{lllll}
\hline Duncan Groupings & N & Means & Group & University Teaching Experience \\
\hline A & 64 & 62.31 & 3 & 12 years and above \\
B & 50 & 61.01 & 2 & $6-11$ years \\
C & 86 & 59.84 & 1 & Below $1-5$ years \\
\hline
\end{tabular}

Table 7 shows the Duncan Multiple Range Test results indicating the source of the significant difference noted in the ANOVA results of Table 6. It can be seen that the means of the three groups differed from one another as depicted by the different Duncan letters A, B, and C. Hence, each of the groups contributed to the significant difference noted in the ANOVA results of Table 6.

\section{Discussion, Conclusions and Recommendations}

Most of the academic staff members agreed that harmonization of academic programmes and qualification can help to promote collaborative research among Economic Community of West Africa Society (ECOWAS) member states. This is in line with Hoosen, Butcher, Beatrice and Khamati (2009) who affirmed that harmonization of academic programmes in Africa can allow information exchange and encourage excellent collaborative research. There was disparity in the perceptions of male and female academic staff members. Diversity in perception can stem from differences in sources of belief, tradition, 
culture and value system (Clark, 1983). In the harmonization policy, it is important to consider the culture of the collaborating countries and the prevailing situations in each country (Amartya, 2000). For harmonization to become effective among member states, gender issues must become a prime consideration in the construction of its philosophy, vision and mission.

Across the various faculties considered in this study there was a general agreement on the need to harmonize academic programmes and qualification in Africa. One of the fundamental aims of this programme is to promote continental research and innovation capacity in science and technology (Woldetensae, 2013). The thematic areas include basic sciences, earth and life sciences, humanities and social sciences. If this is achieved, it will positively boost access to quality education in the West Africa sub-region. The African Union Commission has developed several higher education programmes to foster continental academic integration in order to promote academic development.

Irrespective of the respondent's academic status, there were divergent views on harmonization of academic programmes and qualifications across the subregion. An overview of the programmes showed that this policy will develop comparable standards in line with national and international minimum benchmarks of academic standards. This will result in the development of a set of benchmark standards in all the fields of study, which is in line with the National Qualifications Framework (Hoosen, Butcher\& Khamati, 2009). Through this agenda professional mobility for employment across borders will be made possible and this in turn can promote regional integration.

The results of this study also revealed that the perception of academic staff differs as it relates to university teaching experience of the respondents. Ravaioli (2009) explained that technical standards accommodating specified structures are required in order to allow effective harmonization process and this can be managed through the experience of long standing stakeholders in the university. It is expected that such harmonization would be subjected to the opinions of various stakeholders in the universities, professional bodies and employers of labour, because of their relevant experiences. This might call for a further look at the differences in the perceptions of academic staff in the university on harmonization programme.

This study sheds more light on the initiatives needed to be considered while developing the regional harmonization programme in West Africa. The understanding of these dynamics is essential for counsellors. This will assist counsellors to equip themselves with appropriate information on harmonization polices in West Africa. The knowledge acquired in the process would enable them to give appropriate and effective counselling about the programme to stakeholders. Also policy makers on harmonization can employ the services of 
counsellors in carrying out their programmes in the institution of higher learning.

Therefore, it is recommended that ECOWAS states extend regional integration to further include harmonization of academic programmes within the sub-region. This is expected to foster good relationships among member states. It is also recommended that ECOWAS provides funds to encourage academic activities that foster harmonization among cooperating member states. They can also organize training and workshop for stakeholders on harmonization of academic programmes and qualifications. This will increase and update the knowledge of academic staff in this area. Functioning counselling centres, equipped with professional counsellors, should be established in schools. Counsellors can help in organizing enlightenment programmes in this area on how the ARUSHA programme can positively influence Africa's educational systems.

The researchers are of the opinion that if ECOWAS has become a reality with its glaring notable socio-economic/political opportunities across the subregion, it is also possible to harmonize academic programmes and qualifications in all higher education institutions such that uniformity and mobility can be enhanced among staff and students. The West Africa Examination Council Examination (WASCE) is a typical example of this noble idea. Comparability of the outcomes of educational efforts will be made easier too.

\section{References}

Africa Union (2008). Validation meeting for African quality rating mechanism and harmonization strategy and for higher education. 25th to 27th March 2008 Accra, Ghana AU/AQRM/3 Part I: www.africa-union.org.

Africa Union Commission. (2004). Strategic plan of the Africa Union Commission, Volume 1: Vision and mission of the Africa Union. Addis Ababa: Department of Foreign Affairs Republic of South Africa.

An Explanatory Report to the Convention on Recognition of Qualifications Concerning Higher Education in the European Region. (1997). Lisbon. Retrieved June $11, \quad 2014$ from http://unesdoc.unesco.org/images/0011/001112/111236mb.pdf.

Amartya, S. (2000). Social exclusion: Concept application and scrutiny. A discussion on the concepts of poverty, marginalization and social exclusion.

Bologna Declaration. (1999). The Bologna Declaration of 19 June, 1999. Conference of European Ministers Responsible for Higher Education, Bologna. 
Clark, B. (1983). The higher education system: Academic organization in cross-national perspective. Berkeley: University of California Press.

Hoosen, S., Butcher, N. \& Khamati, B. (2009). Harmonization of higher education programmes: A strategy for the Africa Union.

Ibrahim, A. (2006). Education geared towards needs in New Nigeria. Journal of Education and Policy, 17(4), 5 - 8.

International Conference on Accreditation, Quality Assurance and Recognition of Qualifications in Higher Education in Africa. Hilton Hotel, Nairobi, Kenya, 6-8 February 2006. Retrieved June 16, 2014 from http://www.harare.unesco.org/educquality/papers/NairobiCommuniqu\%C3\%A9-1.pdf

Jokivirta, L. (2006). Foreign higher education activity in francophone Africa. Retrieved June 10, 2014 from http://www.wes.org/ewenr/06apr/feature.htm

Knight, J. (2006). Higher education crossing borders: A guide to the implications of the general agreement on trade in services (GATS) for crossborder education. Paris: Commonwealth of Learning and UNESCO.

Magagula, C. M. (2005). The benefits and challenges of cross-border higher education in developing countries. Boston College \& Council for the Development of Social Science Research in Africa. JHEA/RESA, 3(1), 29 49.

Mason, R. (2006). The university: current challenges and opportunities. In D'Antoni, S. (Ed.) The virtual university, models and messages - lessons from case studies. UNESCO/IIEP

Naidoo, P. (2004). Response to Shabani and Sabaya: The implications of WTO/GATS for higher education in Africa. Proceedings of Accra Workshop on GATS 27th - 29th April 2004 Accra, Ghana. Retrieved 06/15/2014 from: http://www.bc.edu/bc_org/avp/soe/cihe/ihec/regions/gatsproceedings.pdf

Ogbe R. (2007). Information gathered from questionnaire. Retrieved 06/17/2014 http://cbdd.wsu.edu/media/ppt/QualityAssuranceEd.

Ravaioli, S. (2009). Harmonizing higher education: Standard perspectives in support of the Bologna process. Akademik Bilişim, Harran Üniversitesi, Şanlıurfa 11 Şubat - 13 Şubat

Sabaya, W. (2004). Quality assurance, accreditation and recognition of qualifications in Africa: Tanzania's experience and the Arusha Convention. Retrieved June 16, 2014 from http://www.aau.org/wtogats/papers/sabaya.pdf

Sawyerr, A. (2002). Challenges facing African universities - selected issues. Retrieved June 16, 2014 from http://www.aau.org/english/documents/asachallenges.pdf.

Shabani, J. (2004). Regional convention on recognition of studies and degrees of higher education in Africa. Retrieved June 13, 2014 from http://dev.aau.org/wto-gats/papers/shabani.pdf 
UNESCO (2005). Recognition of qualifications. Retrieved June 8, 2014 from http://portal.unesco.org/education/en/ev.php-

URL_ID=40870\&URL_DO=DO_TOPIC\&URL_SECTION=201.html

Wilson, J. (2003). Perspectives on the philosophy of education. Oxford Review of Education, 29(2), 279-283.

Woldetensae, Y. (2013). Africa Union initiatives in higher education. Accra: Academic Mobility Scheme Information. 